\title{
Helium porosity measurements for rocks from unconventional reservoirs performed on crushed samples
}

\begin{abstract}
Porosity measurements for rocks from unconventional reservoirs pose a challenge due to their extremely low permeability, small pore dimensions, and high content of organic matter and clay minerals. The presented work was aimed at adapting the helium porosity measurement methodology for the investigation of microporous rocks. The carried out studies have shown that the measurement conditions are important, which applies both to the measurement pressure and the grain size. The highest porosity values were obtained for measurements performed on samples crushed to grain size $<0.5 \mathrm{~mm}$.
\end{abstract}

Key words: gas-shale, micropores, helium porosity.

\section{Badania porowatości helowej skał ze złóż niekonwencjonalnych na próbkach pokruszonych}

Pomiary porowatości skał ze złóż niekonwencjonalnych stanowią wyzwanie ze względu na bardzo niską przepuszczalność, niewielkie rozmiary porów, wysoką zawartość substancji organicznej i minerałów ilastych. Przedstawiona praca ma na celu przystosowanie metodyki pomiaru porowatości helowej do badań skał mikroporowych. Wykonane badania wykazały, że warunki pomiaru mają tutaj duże znaczenie, dotyczy to zarówno ciśnienia pomiaru i rozmiaru ziaren. Najwyższe wartości porowatości uzyskano dla pomiarów wykonanych na próbkach pokruszonych do frakcji $<0,5 \mathrm{~mm}$.

Słowa kluczowe: łupki gazonośne, mikropory, porowatość helowa.

\section{Introduction}

The term unconventional reservoirs comprises various reservoir types, having the feature that the economically profitable production of hydrocarbons is not possible without the application of stimulating treatments [13]. Such reservoirs exist, inter alia, in tight gas sandstones and gas shale, as gas hydrates and gas in coal deposits [5]. Rocks referred to as "gas shale" include claystones and mudstones characterized by low permeability of the order of tens to hundreds $\mathrm{nD}$, low porosity, usually below $10 \%$, high kerogen and clay mineral content [3]. Observations carried out for rocks from a number of unconventional reservoirs [12] show that in fine grained rocks (mudstones, claystones) there are connected systems of pores of sizes ranging from nanometres to micrometres, related both to the organic matter and to the rock mineral matrix. According to Loucks' classification [9], in microporous rocks it is possible to distinguish three main pore types: pores associated with the organic matter, intergranular pores related to the mineral matrix, and intragranular pores related to the mineral matrix.

Organic-matter nanopores dominate in rocks characterized by high TOC, their amount increasing with growing thermal maturity $[1,13]$. Grains of organic matter frequently contain hundreds of nanopores featuring sizes from $5 \mathrm{~nm}$ to $>800 \mathrm{~nm}$; the nanopore porosity in organic grains ranges from 5.6 to $20 \%$ [10]. Smaller pores exist in rocks containing kerogen in a dispersed form, and voids of larger dimensions are related to organic matter developed in the form of grains and lenses [12]. 
Intergranular pores related to the mineral matrix most often consist of flattened, elongated voids between flakes and aggregates of clay minerals, and other larger detrital grains and crystals of carbonate cements. They feature sizes from less than $1 \mu \mathrm{m}$ to $5 \mu \mathrm{m}$, and occur in rocks of low organic matter content [12]. Intragranular pores exist, among others, in aggregates of clay minerals between individual mineral flakes [9]. In facies enriched with carbonate pellets the intragranular porosity is developed in the form of a network of connected pores with dimensions usually smaller than $1 \mu \mathrm{m}$ existing between coccolith flakes filling the pellets [12]. In rocks rich in iron sulphides there are intercrystalline micropores associated with pyrite framboids.

Porosity measurements in gas shale pose a challenge due to their extremely low permeability, small pore dimensions, and high content of organic matter and clay minerals. Mixed wettability and uneven distribution of media in the pore space are related to the complicated pore structure (systems of pores with dimensions from nanometres to microns associated with both organic matter and rock mineral matrix); brine exists in inorganic pores, while hydrocarbons occur in organic pores $[3,8,13]$. Additional problems with defining the total and effective porosity, distinguishing between "free" and 'bound' water are also related to high clay content, and hence large amounts of immobile water associated with clay minerals in various ways (double layer water, capillary water, interlayered water) [3, 13]. For example, water related to swelling minerals is sometimes considered to be a part of total porosity and sometimes a part of the structure of mixedlayered minerals [13].

Numerous methods are used in porosity measurements for rocks from unconventional reservoirs, both those used for conventional rocks and adapted to measure microporous rocks, such as, e.g. helium porosimetry, mercury porosimetry, NMR measurements, as well as others, like nitrogen adsorption and thermal methods (Dean-Stark, retort, TGA). Results obtained using various methods are usually divergent, which is related to the fact that individual techniques, depending on the measurement method, measure different parts of the pore space [7]. A combination of a few measurement methods, together with the analysis of phenomena affecting the limitations of each of them, provides a possibility for a comprehensive description of the microporous rocks pore space. The comparability of results obtained using the same method is a separate issue; porosity values obtained in various laboratories are frequently substantially different $[11,13]$. This is caused by using different measurement procedures, e.g. measurement on the whole plug or crushed sample, varied size of crushed sample grains.

The presented work was aimed at adapting the helium porosity measurement methodology for the investigation of claystones and mudstones from unconventional deposits. Investigations were carried out on whole plugs and on crushed samples, using various measuring techniques.

\section{Examined material}

Investigations were performed on Lower Paleozoic rocks from M-1 and T-1 boreholes, represented by black bituminous claystones and mudstones with graptolites of relatively similar

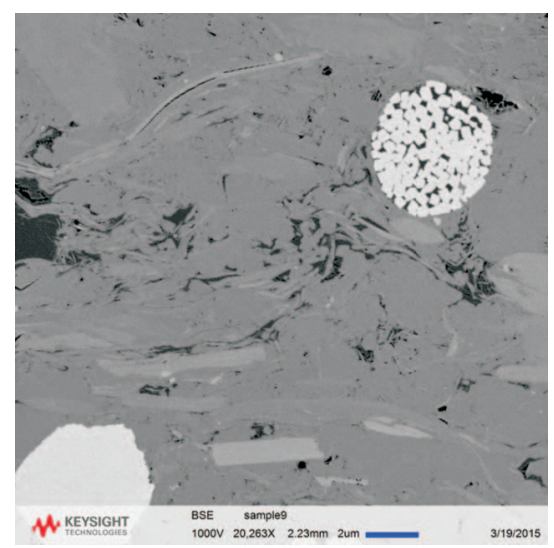

Fig. 1a. Flakes of clay minerals bent due to compaction along the edges of more rigid grains; pyrite framboid, approx. $5 \mathrm{~mm}$ in diameter. Visible intergranular pores between aggregates of clay minerals and along the edges of larger detrital grains, as well as intragranular pores in a pyrite framboid. The majority of pore spaces filled with organic matter - sample 3 mineral composition. Most samples contain on average around $50 \%$ of clay minerals, $25 \div 30 \%$ of quartz, $6.5 \%$ of feldspars, varying amounts of carbonates (from 1 to $10 \%$ ), and quite large

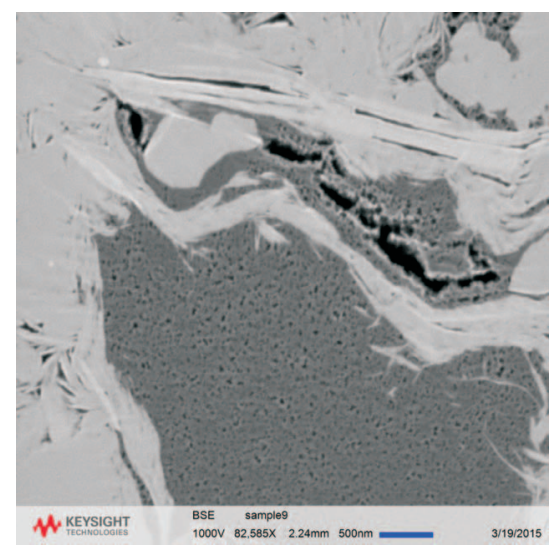

Fig. 1b. Two pore types in organic matter: a network of nanopores of regular, rounded shapes and $10 \div 50 \mathrm{~nm}$ sizes, in the top right corner a long elongated pore of micrometres

size. Also visible triangular intragranular pores between

flakes forming aggregates of clay minerals (bottom left corner) - sample 3 
amounts of pyrite and marcasite (from 4 to $12 \%$ ). The rocks' mineral composition was determined based on quantitative $\mathrm{X}$-ray analysis performed in a standard way in the Department of Well Logging of the Oil and Gas Institute - National Research Institute [6]. Systems of pores related both to the organic matter and to the mineral matrix existing in the studied rocks (Fig. 1a, 1b). A network or nanopores of sizes of around $10 \div 50 \mathrm{~nm}$ and larger was observed in the organic matter, as well as elongated pores of micrometre sizes (Fig. 1b). Intergranular pores are related mainly to clay minerals (Fig. 1a), also occurring along the edges of larger detrital grains (Fig. 1a). Intragranular pores were observed between flakes of clay minerals and in pyrite framboids (Fig. 1a, 1b). Characterisation of the pore space and determination of the type of pores existing in the studied rocks were possible by using a Keysight $8500 \mathrm{~B}$ FE-SEM scanning microscope from Keysight Technologies.

\section{Methodology}

In order to develop a methodology of porosity measurement for crushed samples experimental investigations were carried out for 29 samples of microporous rocks. The influence of both measurement pressure and the degree the material disintegration on the obtained results was studied.

In the Department of Well Logging helium porosity is determined using two instruments working together: AccuPyc 1330 helium pycnometer, measuring grain density, and GeoPyc 1360 instrument measuring bulk density. Such measurements are performed in a standard way on a plug dried for $24 \mathrm{~h}$ at $105^{\circ} \mathrm{C}$

$$
K p=\left(1-\frac{\rho_{b}}{\rho_{p l}}\right) \cdot 100 \%
$$

where:

$K p$ - porosity determined on the plug,

$\rho_{b}$ - bulk density,

$\rho_{p l}$ - grain density of the plug.

In porosity measurements for rocks from unconventional reservoirs grain density measured on samples crushed to a specified fraction is used $[2,11,13]$, which facilitates helium penetration into the pore space.

$$
K p=\left(1-\frac{\rho_{b}}{\rho_{g r}}\right) \cdot 100 \%
$$

where:

$K p$ - porosity obtained for grain density measured on crushed sample,

$\rho_{b}$ - bulk density,

$\rho_{g r}-$ grain density of crushed sample.

The introduction of volumetric porosity measurement on a crushed sample was an interesting solution in porosity measurements for microporous rocks. This method allows the avoidance of errors related to insufficient drying of the sample, i.e. overestimating the plug mass, and hence the bulk density value. The basic assumption of this methodology is preservation of the plug volume after crushing (the plug is crushed in such a way as not to lose more than $0.75 \%$ of the mass) [4]. For the majority of measured samples the relative error related to the loss of mass does not exceed this value. Samples for which the loss of mass exceeded $0.75 \%$ were rejected from calculations. In addition, a reduction of error related to the loss of mass was obtained by introducing a corrected value of crushed sample volume $V_{g r 1}$.

$$
V_{g r 1}=V_{g r}+\frac{\Delta m}{\rho_{g r}}
$$

where:

$V_{g r 1}$ - corrected grain volume of crushed sample,

$V_{g r}$ - grain volume of crushed sample,

$\Delta m$ - loss of sample mas,

$\rho_{g r} \quad-$ grain density of crushed sample.

$$
K p=\left(1-\frac{V_{g r 1}}{V_{b}}\right) \cdot 100 \%
$$

where:

$K p$ - porosity calculated from volume, volume of the whole plug is preserved (crushing in a specially designed mortar, Fig. 2),

$V_{g r 1}$ - corrected grain volume of crushed sample, $V_{b}$ - bulk volume.

The following measurement procedure was adopted, which enabled determination of porosity using both the density and the volumetric method:

1. Measurement of the grain density of the plug $\rho_{p l}$ using the AccuPyc 1330 helium pyconmeter at pressures of 19.50 psi and 100 psi.

2. Measurement of the plug bulk density $\rho_{b}$ using the GeoPyc 1360 instrument.

3. Crushing the sample to the fraction below $0.5 \mathrm{~cm}$ (the size of fragments was adopted based on the literature data) [11]. To preserve the entire rock material from the plug, samples were crushed in a special mortar (Fig. 2) and then transferred to the measuring vessel of the AccuPyc instrument. In accordance with the literature [4], 
the assumption was made that the loss of mass should not exceed $0.75 \%$ of the plug weight.

4. Measurement of the grain density a sample crushed to $<0.5 \mathrm{~cm}$ fraction $-\rho_{<0.5 \mathrm{~cm}}$ using the AccuPyc 1330 helium pycnometer at a measurement pressure of $100 \mathrm{psi}^{1}$.

5. Measurement of the grain density of a sample crushed to $<0.5 \mathrm{~mm}$ fraction $-\rho_{<0.5 \mathrm{~mm}}$ using the AccuPyc 1330 helium pycnometer at a pressure of 100 psi.

6. Measurement of the grain density of a sample crushed to $<0.1 \mathrm{~mm}$ fraction $-\rho_{<0.1 \mathrm{~mm}}$ using the AccuPyc 1330 helium pycnometer at a pressure of 100 psi (made for 10 samples).

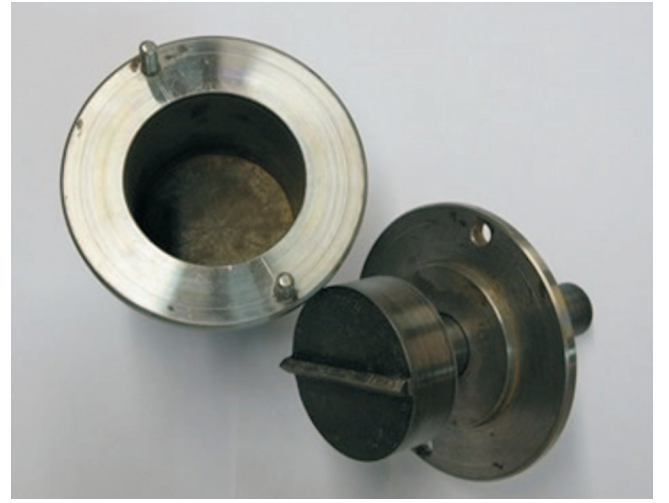

Fig. 2. Mortar used to crush samples so as to eliminate the loss of mass

\section{Results}

The values of density and porosity obtained for all studied samples, for measurements on the entire plug and on the sample crushed to fractions $<0.5 \mathrm{~cm},<0.5 \mathrm{~mm}$ and $<0.1 \mathrm{~mm}$ are presented in Table 1.

\section{Grain density}

Results of the grain density measurements using the helium pycnometer show the influence of both measurement pressure and of the degree of studied material disintegration on the obtained values. The lowest values of the grain density were obtained for measurements on the entire plug at the pressure of 19.50 psi (Table 1, Fig. 3). The increase of the measurement pressure to 100 psi resulted in a small rise in the grain density value (Table 1, Fig. 3), which proves better helium penetration into the pore space. Because of that, measurements on crushed samples were performed at a pressure of 100 psi. Crushing of the sample (fragment size below $0.5 \mathrm{~cm}$ ) resulted in a distinct increase in the grain density value (Table 1, Fig. 3). The highest grain density values were obtained, in most cases, for samples crushed to below $0.5 \mathrm{~mm}$ fraction (Table 1, Fig. 3). Only for two samples (samples 1,2) a higher grain density value was obtained measurements conducted on larger fragments (below $0.5 \mathrm{~cm}$ ) (Table 1, Fig. 3). To check whether further reduction of fraction would affect results, measurements were carried out on 10 samples crushed to $<0.1 \mathrm{~mm}$ fraction. This treatment did not result in an increased value of grain density (Table 1).

\section{Porosity}

Five porosity values were obtained as a result of the performed measurements:

1) $K p_{l}$ - porosity determined on the plug at a pressure of 19.50 psi,

2) $K p_{p l 100}$ - porosity determined on the plug at a pressure of 100 psi,

3) $K p_{V}$ - porosity obtained for grain density measured on sample crushed to $<0.5 \mathrm{~cm}$ fraction, calculated based on volume,

4) $K p_{<0.5 \mathrm{~cm}}$ - porosity obtained for grain density measured on sample crushed to $<0.5 \mathrm{~cm}$ fraction, calculated based on density,

5) $K p_{<0.5 \mathrm{~mm}}$ - porosity obtained for grain density measured on sample crushed to $<0.5 \mathrm{~mm}$ fraction.

A clear differentiation of obtained values was found. Porosities calculated for measurements on the plug are definitely lower than those obtained for the crushed samples (Table 1, Fig. 4). Many of them take negative values, which proves the decidedly undestimated value of the grain density. Values obtained from measurements at a pressure of $100 \mathrm{psi}\left(K p_{p l 100}\right)$ are higher than values obtained for a pressure of $19.50 \mathrm{psi}$ $\left(K p_{p l}\right)$, but there are still some negative values (Table 1, Fig. 4). Porosity values for crushed samples calculated by means of the volumetric method $\left(K p_{V}\right)$ are slightly higher than values calculated using the density method (Table 1, Fig. 4). For most samples the highest porosity values were obtained for measurements on material crushed to $<0.5 \mathrm{~mm}$ fraction $\left(K p_{<0.5 \mathrm{~mm}}\right)$, which proves that the degree of pore space penetration by helium molecules has the greatest influence on the porosity value measured for microporous rocks.

\section{Relationship between porosity and mineral composition}

No clear relationships between mineral composition and porosity were found in the investigated rocks. Only a trend of porosity growing with increasing quartz content was observed. The most visible trend was obtained for porosity values calculated for the sample crushed to $<0.5 \mathrm{~mm}$ fraction $K p_{<0.5 \mathrm{~mm}}$ (Fig. 5).

${ }^{1}$ The choice of pressure for measurements on crushed samples was dictated by results obtained for plugs. 
Table 1. Results of density and porosity measurements on plugs and on crushed samples

\begin{tabular}{|c|c|c|c|c|c|c|c|c|c|c|}
\hline \multirow{2}{*}{$\begin{array}{c}\text { No of } \\
\text { sample }\end{array}$} & \multicolumn{2}{|c|}{ Plug density } & \multicolumn{3}{|c|}{ Crushed sample density } & \multicolumn{2}{|c|}{ Plug porosity } & \multicolumn{3}{|c|}{ Crushed sample porosity } \\
\hline & $\begin{array}{c}\rho_{p l} \\
{\left[\mathrm{~g} / \mathrm{cm}^{3}\right]}\end{array}$ & $\begin{array}{c}\rho_{p / 100} \\
{\left[\mathrm{~g} / \mathrm{cm}^{3}\right]}\end{array}$ & $\begin{array}{l}\rho_{<0.5 \mathrm{~cm}} \\
{\left[\mathrm{~g} / \mathrm{cm}^{3}\right]}\end{array}$ & $\begin{array}{l}\rho_{<0.5 \mathrm{~mm}} \\
{\left[\mathrm{~g} / \mathrm{cm}^{3}\right]}\end{array}$ & $\begin{array}{l}\rho_{<0.1 \mathrm{~mm}} \\
{\left[\mathrm{~g} / \mathrm{cm}^{3}\right]}\end{array}$ & $\begin{array}{l}K p_{p l} \\
{[\%]}\end{array}$ & $\begin{array}{c}K p_{p l 100} \\
{[\%]}\end{array}$ & $\begin{array}{l}K p_{V} \\
{[\%]}\end{array}$ & $\begin{array}{c}K p_{<0.5 \mathrm{~cm}} \\
{[\%]}\end{array}$ & $\begin{array}{c}K p_{<0.5 \mathrm{~mm}} \\
{[\%]}\end{array}$ \\
\hline 1 & 2.676 & 2.724 & 2.748 & 2.728 & 2.737 & -0.37 & 1.40 & 2.41 & 2.26 & 1.54 \\
\hline 2 & 2.687 & 2.708 & 2.747 & 2.721 & 2.730 & 1.34 & 2.10 & 3.65 & 3.49 & 2.57 \\
\hline 3 & 2.520 & 2.540 & 2.544 & 2.562 & & -0.52 & 0.28 & & 0.43 & 1.12 \\
\hline 4 & 2.591 & 2.609 & 2.605 & 2.649 & 2.677 & -1.78 & -1.07 & -0.91 & -1.23 & 0.45 \\
\hline 5 & 2.593 & 2.602 & 2.659 & 2.678 & 2.646 & -0.73 & -0.38 & 1.94 & 1.77 & 2.46 \\
\hline 6 & 2.593 & 2.590 & 2.642 & 2.682 & 2.667 & -1.08 & -1.19 & 1.48 & 0.80 & 2.27 \\
\hline 7 & 2.574 & 2.577 & 2.612 & 2.617 & & -0.04 & 0.08 & 1.59 & 1.42 & 1.60 \\
\hline 8 & 2.646 & 2.654 & 2.728 & 2.724 & & 0.19 & 0.49 & 3.33 & 3.19 & 3.03 \\
\hline 9 & 2.512 & 2.533 & 2.575 & 2.593 & & -0.36 & 0.47 & 2.23 & 2.10 & 2.78 \\
\hline 10 & 2.486 & 2.522 & 2.541 & 2.548 & & 0.56 & 1.98 & 2.78 & 2.70 & 2.99 \\
\hline 11 & 2.478 & 2.499 & 2.535 & 2.549 & & 0.36 & 1.20 & 2.76 & 2.60 & 3.12 \\
\hline 12 & 2.502 & 2.535 & 2.555 & 2.560 & & -0.24 & 1.07 & 2.18 & 1.84 & 2.02 \\
\hline 13 & 2.483 & 2.536 & 2.562 & 2.566 & & 1.37 & 3.43 & 4.57 & 4.40 & 4.56 \\
\hline 14 & 2.613 & 2.621 & 2.659 & 2.694 & & 0.15 & 0.46 & 2.57 & 1.88 & 3.16 \\
\hline 15 & 2.673 & 2.671 & 2.743 & 2.758 & & -0.94 & -1.01 & 2.20 & 1.64 & 2.17 \\
\hline 16 & 2.659 & 2.694 & 2.725 & 2.717 & & 1.17 & 2.45 & 3.80 & 3.56 & 3.29 \\
\hline 17 & 2.675 & 2.691 & 2.742 & 2.759 & 2.741 & 1.23 & 1.82 & 3.83 & 3.64 & 4.24 \\
\hline 18 & 2.662 & 2.659 & 2.715 & 2.735 & 2.717 & -0.49 & -0.60 & & 1.46 & 2.18 \\
\hline 19 & 2.546 & 2.584 & 2.607 & 2.620 & & 0.31 & 1.78 & 2.81 & 2.65 & 3.13 \\
\hline 20 & 2.543 & 2.569 & 2.617 & 2.622 & & 1.26 & 2.26 & 4.27 & 4.05 & 4.22 \\
\hline 21 & 2.671 & 2.673 & 2.708 & 2.719 & 2.719 & 0.15 & 0.22 & 1.67 & 1.50 & 1.91 \\
\hline 22 & 2.628 & 2.627 & 2.702 & 2.689 & & 0.00 & -0.04 & & 2.74 & 2.26 \\
\hline 23 & 2.628 & 2.640 & 2.712 & 2.703 & 2.701 & -0.72 & -0.27 & 2.60 & 2.38 & 2.07 \\
\hline 24 & 2.642 & 2.687 & 2.713 & 2.718 & & 0.79 & 2.46 & 3.57 & 3.41 & 3.57 \\
\hline 25 & 2.561 & 2.560 & 2.599 & 2.627 & & 0.20 & 0.16 & & 1.65 & 2.70 \\
\hline 26 & 2.485 & 2.534 & 2.564 & 2.562 & & 1.21 & 3.12 & 4.37 & 4.25 & 4.18 \\
\hline 27 & 2.515 & 2.523 & 2.578 & 2.599 & & -0.04 & 0.28 & 2.54 & 2.40 & 3.19 \\
\hline 28 & 2.672 & 2.693 & 2.735 & 2.744 & & -0.30 & 0.48 & 2.10 & 2.01 & 2.33 \\
\hline 29 & 2.642 & 2.649 & 2.725 & 2.724 & & 0.08 & 0.34 & & 3.11 & 3.08 \\
\hline
\end{tabular}

Explanations: $\rho_{p l}$ - grain density of the plug (pressure of $\left.19.50 \mathrm{psi}\right) ; \rho_{p l 100}-$ grain density of the plug (pressure of $100 \mathrm{psi}$ ); $\rho_{<0.5 \mathrm{~cm}}-$ grain density of crushed sample, $\rho_{<0.5 \mathrm{~mm}}$ - grain density measured on sample crushed to $<0.5 \mathrm{~mm}$ fraction, $\rho_{<0.1 \mathrm{~mm}}$ - grain density measured on sample crushed to $<0.1 \mathrm{~mm}$ fraction; $K p_{p l}$ - porosity measured on the plug (pressure of $19.50 \mathrm{psi}$ ); $K p_{p l 100}$ - porosity measured on the plug (pressure of $100 \mathrm{psi}$ ); $K p_{V}$ - porosity obtained for grain density measured on crushed sample, calculation based on volume; $K p_{<0.5 \mathrm{~cm}}-$ porosity obtained for grain density measured on crushed sample, calculation based on density; $K p_{<0.5 \mathrm{~mm}}$ - porosity obtained for grain density measured on sample crushed to $<0.5 \mathrm{~mm}$ fraction. 


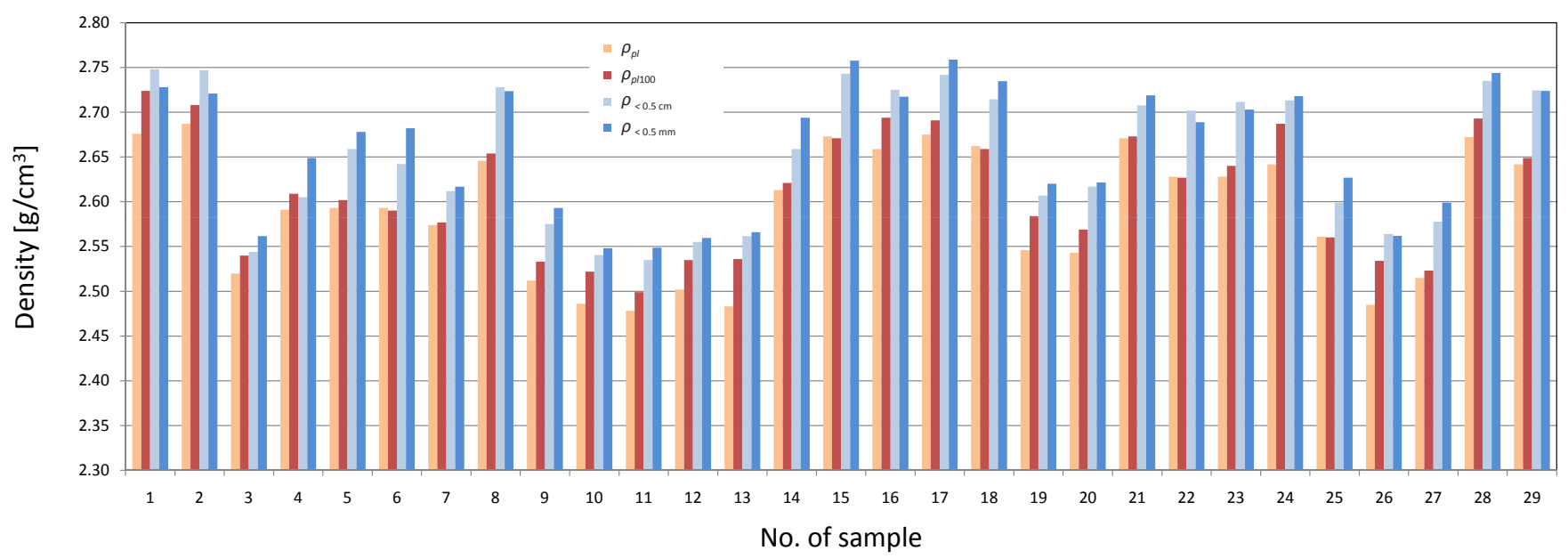

Fig. 3. Comparison of grain density values measured on the whole plug and crushed samples: $\rho_{p l}-$ plug grain density (pressure of $19.50 \mathrm{psi}$ ); $\rho_{p l 100}$ - plug grain density (pressure of $100 \mathrm{psi}$ ); $\rho_{<0.5 \mathrm{~cm}}$ - grain density on sample crushed to $<0.5 \mathrm{~cm}$ fraction; $\rho_{<0.5 \mathrm{~mm}}-$ grain density measured on sample crushed to $<0.5 \mathrm{~mm}$ fraction

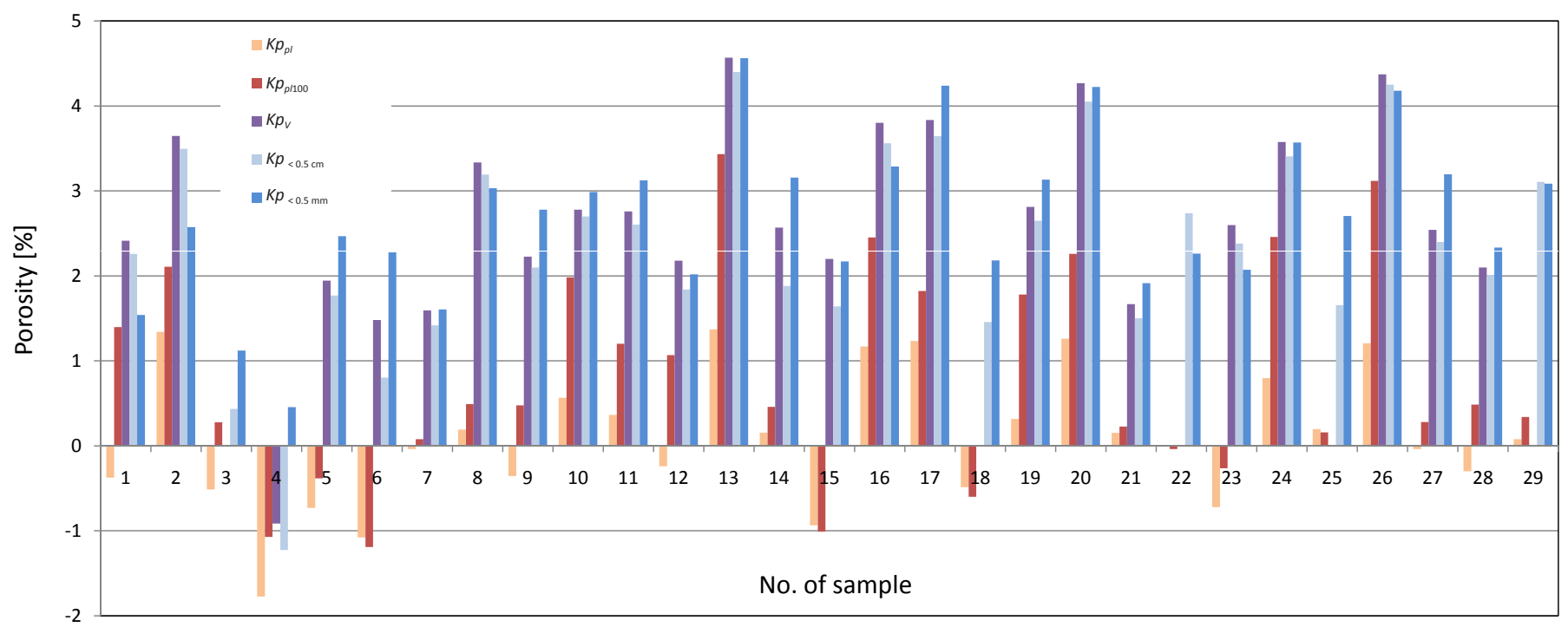

Fig. 4. Comparison of different porosity values: $K p_{p l}$ - porosity measured on the plug at a pressure of $19.50 \mathrm{psi}$; $K p_{p l 100}$ - porosity measured on the plug at a pressure of $100 \mathrm{psi} ; K p_{V}$ - porosity obtained for the grain density measured on sample crushed to $<0.5 \mathrm{~cm}$ fraction, calculated based on volume; $K p_{<0.5 \mathrm{~cm}}$ - porosity obtained for the grain density measured on sample crushed to $<0.5 \mathrm{~cm}$ fraction, calculated based on density; $K p_{<0.5 \mathrm{~mm}}-$ porosity obtained for grain density measured on sample crushed to $<0.5 \mathrm{~mm}$ fraction

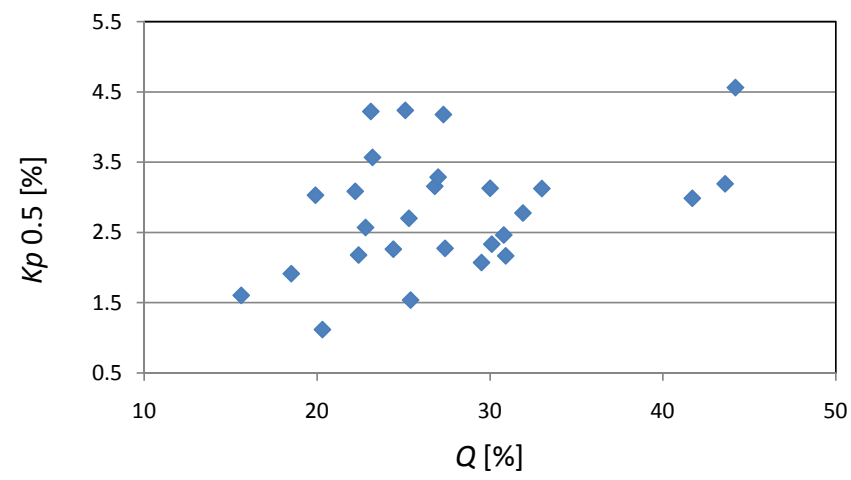

Fig. 5. Relationship between porosity and quartz content 


\section{Summary and Conclusions}

The carried out studies show that the measurement conditions are important for microporous rocks, which applies both to the measurement pressure and to the grain size. The highest porosity values were obtained for measurements performed on samples crushed to $<0.5 \mathrm{~mm}$ fraction. Values of porosity measured on the entire plug are underrated, which is related to the underestimated grain density value. Measurement pressure increased from 19.50 psi to 100 psi caused in most cases an increase in porosity. However, these values are substantially frequently a few or even ten times - lower than results obtained for crushed samples. This shows that for microporous rocks of low permeability, like gas shale, helium molecules cannot penetrate into the pore space of the plug during the given time of measurement. Only crushing of the sample makes the pore space available to a larger degree, enables more effective drying of the sample and access to the finest pores. Porosity values obtained using the volumetric method $\left(K p_{V}\right)$ are slightly higher than those obtained by means of density methods for the same grain size fraction $\left(K p_{<0.5 \mathrm{~cm}}\right)$, but in most cases lower than porosities obtained for the grain size fraction $<0.5 \mathrm{~mm}$ $\left(K p_{<0.5 \mathrm{~mm}}\right)$. This confirms that making the pore space available through the appropriate choice of the grain size fraction is the most important factor affecting the porosity value.
No correlation was observed between porosity and clay minerals, which is related to the fact that the pore space of the studied rocks is associated with both clay minerals and to organic matter. Instead, a trend of porosity growing with increasing quartz content was noticed. This is related to the effect, described in the literature [14], that mechanically resistant grains, like quartz, existing in the clay matrix create a kind of support for flexible mica flakes and so prevent closing of pores.

Porosity values obtained under optimum measurement conditions (for samples crushed to $<0.5 \mathrm{~mm}$ fraction) for most samples range from 1.5 to $4.5 \%$. The question arises here of how porosity measured in this way should be defined. It is necessary to remember that crushing of a sample does not have to make the pore space entirely available: pores inaccessible to helium (due to too small dimensions or/and insufficient drying of the sample) can exist in the crushed material.

So it seems advisable to continue studies on the pore space by combining the method of helium porosimetry with nitrogen adsorption measurements, which allow reaching of the smallest nanopores in the organic matter, and with NMR studies giving the total porosity value.

Please cite as: Nafta-Gaz 2015, no. 11, pp. 856-863, 10.18668/NG2015.11.07

Article contributed to the Editor 4.09.2015. Approved for publication 15.10.2015.

The article is the result of research conducted in connection with the project: The methodology for determining sweet spots on the basis of geochemical, petrophysical, geomechanical properties based on the correlation of laboratory test results with geophysical measurements and 3D generating model, co-funded by the National Centre for Research and Development as part of the programme BLUE GAS - POLISH SHALE GAS. Contract No. BG1/MWSSSG/13.

\section{Literature}

[1] Bernard S., Wirth R., Schreiber A., Bowen L., Aplin A. C., Mathia E. J., Horsfield B., Schulz H.: FIB-SEM and TEM investigations of an organic-rich shale maturation series from the lower Toarcian Posidonia Shale, Germany: Nanoscale pore system and fluid-rock interactions. [W:] Camp W., Diaz E., Wawak B. (Eds.): Electron microscopy of shale hydrocarbon reservoirs. AAPG Memoir 2013, 102, pp. 53-66.

[2] Darlak B., Kowalska-Wlodarczyk M., Such P.: Methodological aspects of porosity and pore space measurements in shale rocks. Nafta-Gaz 2011, no. 5, pp. 326-330.

[3] Handwerger D. A., Suarez-Rivera R., Vaughn K. I., Keller J. F.: Improved Petrophysical Core measurements on Tight Shale Reservoirs Using Retort and Crushed Samples. Society of Petroleum Engineers Annual Conference and Exhibition, Denver, Colorado 30 October-2 November 2011, SPE Paper 147456.

[4] Karastathis A.: Petrophysical measurements on tight gas shale. Master of Science Thesis, University of Oklahoma, 2007.

[5] Kiersnowski H., Buniak A., Kuberska M., Srokowska-Okonska A.: Wystepowanie gazu ziemnego zamknietego w piaskow- cach czerwonego spagowca Polski. Przegląd Geologiczny 2010, vol. 58, no. 4.

[6] Kowalska S.: Okreslenie ilosciowego skladu mineralnego skal zawierajacych mineraly ilaste metoda Rietvelda. Nafta-Gaz 2013, no. 12, pp. 894-902.

[7] Kuila U., Saidian M., Godinez L. J., Rivera S., Prasad M.: A Comparative Study of Porosity Measurement in MudRocks. SEG Denver Annual Meeting 2014, 2433-2437.

[8] Labus M., Labus K., Bujok P.: Determination of the pore space parameters in microporous rocks by means of thermal methods. Journal of Petroleum Science and Engineering 2015, vol. 127, pp. 482-489.

[9] Loucks R. G., Reed R. M., Ruppel S. C., Hammes U.: Spectrum of pore types and networks in mudrocks and a descriptive classification for matrix-related mudrock pores. AAPG Bulletin 2012, vol. 96, no. 6, pp. 1071-1098.

[10] Loucks R. G., Reed R. M., Ruppel S. C., Jarvie D. M: Morphology, Genesis and Distribution of Nanometer-Scale Pores in Siliceous Mudstones of the Mississipian Barnett Shale. Journal of Sedimentary Research 2009, vol. 79, pp. 848-861. 
[11] Luffel D. L., Guidry F. K.: New Core Analysis Methods for Measuring Reservoir Rock Properties of Devonian Shale. Journal of Petroleum Technology 1992, vol. 44(11), pp. 1184-1190. DOI: 10.2118/20571-PA.

[12] Milner M., McLin R., Petriello J.: Imaging Texture and Porosity in Mudstones and Shales: Comparison of Secondary and Ion-Milled backscatter SEM Methods. Canadian Society for Unconventional Gas/Society of Petroleum Engineers Canadian Unconventional Resources and International Petroleum Conference, Calgary, Alberta 19-21 October 2010, SPE Paper 138975, pp. 1-10.

[13] Passey Q. R., Bohacs K. M., Esch W. L., Klimentidis R., Sinha S.: From Oil-Prone Source Rock to Gas-Producing Shale Reservoir - Geologic and Petrophysical Characterization of Unconventional Shale-Gas Reservoirs. CPS/SPE International Oil \& Gas Conference and Exhibition, Bejing 8-10 June 2010.

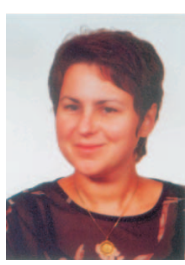

Anna PRZELASKOWSKA M.Sc

Senior Research Support Specialist, Department of

Well Logging

Oil and Gas Institute - National Research Institute

ul. Lubicz 25 A

31-503 Kraków

E-mail: anna.przelaskowska@inig.pl
[14] Schieber J.: SEM Observations on Ion-milled Samples of Devonian Black Shales from Indiana and New York: The Petrographic Context of Multiple Pore Types. [W:] Camp W., Diaz E., Wawak B. (Eds.): Electron microscopy of shale hydrocarbon reservoirs. AAPG Memoir 2013, 102, pp. 153-171.

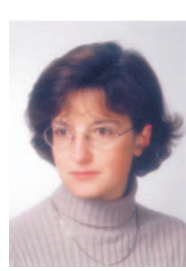

Jolanta KLAJA M.Sc., Eng.

Research Support Specialist, Department of Well

Logging

Oil and Gas Institute - National Research Institute

ul. Lubicz 25 A

31-503 Kraków

E-mail:klaja@inig.pl

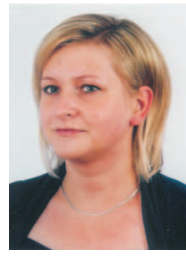

Grażyna ŁYKOWSKA

Assistant, Department of Well Logging; Quality

Manager at Laboratory of Well Logging

Oil and Gas Institute - National Research Institute

ul. Lubicz 25 A

31-503 Kraków

E-mail: grazyna.lykowska@inig.pl

\section{OFFER}

\section{DEPARTMENT OF WELL LOGGING}

Scope of activity:

- 3-D visualization and analysis of the structure of pore space of rocks using micro computed tomography;

- determination of the water saturation distribution in the pore space of rocks and cement stone samples by the nuclear magnetic resonance (NMR) method;

- determination of the qualitative and quantitative mineral composition of rocks, and separated clay fraction on the basis of $\mathrm{X}$-ray analysis (XRD);

- determination of the content of natural radioactive elements: uranium, thorium, and potassium in rocks, drilling muds and construction materials;

- evaluation of the electrical parameters of rocks (cementation exponent " $\mathrm{m}$ ", saturation exponent " $\mathrm{n}$ ");

- determination of the dependence of temperature on the specific electrical resistivity of drilling muds;

- measurements of the transverse (share) and longitudinal (compressional) wave with the use of the ultrasonic method in rocks, cement stones and drilling muds;

- determination of thermal conductivity of rocks;

- determination of specific density, volume density and total porosity of rocks cores;

- measurements of gas permeability of rocks core samples;

- interpretation of geophysical loggings in respect of the cementing state of the casing string in the boreholes;

- well site services:

» determination of total and spectral $(U, T h, K)$ gamma anlysis with the use of well site gamma logger,

" chemical analysis of rocks with the use of XRF method.

CONTACT

Marek Dohnalik, PhD Eng.

Address: 1 Bagrowa Str., 30-733 Cracow, POLAND

Phone: +48126506770 Fax: +48 126177470

E-mail: marek.dohnalik@inig.pl 